\title{
ARTICLE
}

\section{Early Election Calling and Satisfaction with Democracy}

\author{
Edward Morgan-Jones ${ }^{1 \star}$ (D) and Mathew Loveless ${ }^{2}$ (D) \\ ${ }^{1}$ School of Politics and International Relations, University of Kent, Canterbury, UK and ${ }^{2}$ Department of \\ Political and Social Sciences, University of Bologna, Bologna, Italy \\ ${ }^{*}$ Corresponding author. Email: E.Morgan-Jones@kent.ac.uk
}

(Received 23 July 2020; revised 20 May 2021; accepted 16 July 2021)

\begin{abstract}
Many countries have constitutional rules, granted to prime ministers, presidents or cabinets, that govern early parliamentary dissolution. Although there are sharply divergent theoretical expectations about the consequences of such powers for both democratic representation and accountability, there have been no empirical examinations of these arguments. Using data from the European Social Survey (2002-16) in 26 European countries, we test whether such provisions for early election calling affect citizens' satisfaction with democracy, and if so, which rules and how. While it appears that no form of constitutional rules for early election is directly related to citizen satisfaction with democracy, when early elections are called by prime ministers or presidents, democratic satisfaction drops significantly, and this effect is more pronounced the later in the term the early election is called. These findings have important implications for academic and policy debates about the desirability of constitutional change designed to limit early election calling for opportunistic purposes.
\end{abstract}

Keywords: constitutional rules; parliamentary early elections; satisfaction with democracy

In representative democracies, competitive elections provide the most important instruments for citizens to select public officials that share their views. Elections are also the central opportunity citizens can use to hold their rulers accountable for their performance in office (Fearon 1999; Powell 2004). Although, when citizens have access to these instruments varies across parliamentary and semi-presidential democracies. In such regimes, the timing of assembly elections is typically flexible rather than fixed. For example, in Europe's democracies, $40 \%$ of elections are called early before the constitutionally mandated end of the parliamentary term (Schleiter and Tavits 2016: 841).

It is now well established that constitutional rules regulate the ease with which such early elections can be called. Early elections are more common when prime ministers and cabinets have constitutional discretion to call early elections

(C) The Author(s), 2021. Published by Cambridge University Press on behalf of Government and Opposition Limited. This is an Open Access article, distributed under the terms of the Creative Commons Attribution licence (https://creativecommons.org/licenses/by/4.0/), which permits unrestricted re-use, distribution, and reproduction in any medium, provided the original work is properly cited. 
(Schleiter and Morgan-Jones 2009: 506-507; Strøm and Swindle 2002: 587-588). In these cases, prime ministers can choose to time elections so that voters' ballots are cast in conditions favourable to incumbent re-election (Chowdhury 1993; Ito 1990; Ito and Park 1988; Kayser 2005, 2006; Palmer and Whitten 2000). Carefully timing these elections enables incumbents to increase their parties' vote and seat share, enhancing the likelihood that they will retain the post of prime minister (Schleiter and Tavits 2016: 847). Presidents in parliamentary and semi-presidential regimes, if granted powers to call early elections, may also influence electoral timing to shape the electoral success of prime-ministerial incumbents to which they are allied (Schleiter and Morgan-Jones 2018). However, as Petra Schleiter and Margit Tavits point out, 'an incumbent's ability to control election timing can fundamentally affect the outcomes of democratic accountability ... Because the economic and political environment influences vote choice, political leaders can affect how voters vote by controlling when they vote .... [O]pportunistically timed elections allow leaders to better secure their desired outcomes' (2016: 848). If citizens' abilities to use elections to secure representation and accountability are moderated by constitutional rules that permit prime ministers, cabinets and presidents to call early elections, this has an implication for the quality of democracy.

In the light of ongoing policy debates and contrasting practices in the constitutional rules that regulate the dissolution of parliament, we ask, what does the degree of executive control over the timing of pre-term parliamentary elections called mean for citizens' subjective satisfaction with democracy? We first identify the divergent theoretical arguments in the literature about the way that constitutional rules governing early parliamentary dissolution may shape citizen experience and thus evaluations of democracy. One view implies that constraining the ability of prime ministers to call early elections should increase satisfaction with democracy, as opportunistic early election calling appears as a means for politicians to evade accountability. Another view suggests that constraining early elections decreases executive performance, making governments on average more unstable and less able to pass and sustain their policy agendas (Cheibub and Przeworski 1999: 236; Hellwig and Samuels 2008: 70-71; Laver 2008: 124-125), in turn reducing citizen democratic satisfaction. Either view would have implications for the impact of actual early election calling in the short term on democratic satisfaction as it sends a signal to the electorate about incumbent quality (Smith 2004).

Second, using data from Rounds 1 to 8 of the European Social Survey (ESS) (2002-16) in 26 European countries, we test whether such provisions for early election calling affect citizens' satisfaction with democracy, and if so, which ones and how. We find first no evidence that the mere presence of constitutional rules for early election calling is directly related to citizen satisfaction with democracy. However, when early elections are called by prime ministers or presidents, democratic satisfaction drops significantly. This effect is pronounced the closer the early election is called to a regularly scheduled parliamentary election. These findings take the study of the constitutional rules governing early election calling beyond a focus on the political processes they generate to consider their implications for citizens' attitudes towards democracy.

Changes in individuals' levels of satisfaction with the performance of democratic institutions has been a crucial indicator of national health (Anderson 2005; 
Claassen 2020) and has served as a key metric for democratic socialization in countries undergoing democratization (Evans and Whitefield 1995; Rohrschneider 1999; Rose and Mishler 1994). Specific to the cases under investigation here, individuals' satisfaction with democracy is not inconsequential in the current political and economic climate. The drive for Catalonian independence, Brexit, the rise of soft dictators in Eastern Europe, the migration question, regional autonomy movements, the rise of both extreme and new parties, and terrorism represent only the most visible contemporary and concurrent events that directly challenge nation states and the endurance of the European Union project - a project clearly legitimized only by the sufficient and continued popular support of its citizens (Loveless and Rohrschneider 2011).

\section{Constitutional rules, early elections and accountability}

Over the last 20 years, political scientists have established the central role that the constitutional rules governing early election calling play in democratic governance, identifying the effects of these institutional rules on key democratic processes. These include the timing of elections (Kayser 2005; Smith 2004, Strøm and Swindle 2002), the making and breaking of governments (Schleiter and Morgan-Jones 2009), incumbent electoral success (Schleiter and Tavits 2016), the economic consequences of early election calling (Smith 2004) and the ability of the executive to achieve its legislative and public policy goals (Becher and Christiansen 2015). Thus, in the context of such observed effects, it is not unreasonable to expect meaningful differences in how citizens view these changes in governance processes when incumbents can call elections freely compared with those in which they cannot. Yet, despite clear implications in the literature about the way that citizens experience and thus evaluate the performance of democracy, there is a gap in our empirical knowledge in how the differences in the early elections capabilities potentially impact citizens' attitudes towards democracy.

A parallel gap in the literature on citizen satisfaction with democracy has also emerged. This has emphasized that citizen experience of democracy is mediated by institutions (Aarts and Thomassen 2008; Anderson and Guillory 1997; Rohrschneider 1999, 2005). The main set of institutions that this literature has focused upon is electoral and party systems as well as government capacity to respond to citizen demands (Wagner et al. 2009), primarily because of effects these institutions are thought to have on citizens' experience of representation and accountability. If, as Max Goplerud and Petra Schleiter argue, 'the political consequences of constitutional powers to call early elections ... may be comparable with those of electoral rules' because they 'condition electoral accountability, incumbency advantages, governments, and policy' (Goplerud and Schleiter 2016: 428), this motivates a similar investigation into how constitutional rules shape citizens' perceptions of the quality of their democracy experiences. A natural question arising for the democratic satisfaction literature is therefore, do parliamentary dissolution powers shape citizen satisfaction with democracy? In the next section of the article, we ask whether these constitutional differences in the rules governing 
early election calling have the potential to shape citizens' evaluations of democratic quality, and if so, how?

\section{Constitutional rules and citizens' perceptions of democratic quality}

Below we develop theoretical arguments about the link between the rules governing early election calling and citizens' evaluation of democratic quality. To develop the theoretical links between constitutional rules governing early election calling and citizen satisfaction with democracy we build on two sets of work with different focuses. The first set of work we discuss considers the systematic effects of rules governing early elections and their effects on democratic governance, with implications for democratic quality. This set of literature identifies long-term effects that the rules on early election might have on individual democratic satisfaction across polities with different constitutional rules. The second set of literature focuses on the short-term meaning and impact of calling early elections on citizens' evaluations of the incumbent, which may have implications for individual evaluations of democratic performance at the time when early elections are called.

We start our discussion with the literature that focuses on the macro-effects of different constitutional rules on democratic performance and accountability. This literature's key insight is that that differences in the constitutional rules governing early elections promote different patterns of election calling and government termination. These patterns result from incentives and constraints that these rules provide to politicians and have consequences for the quality of democratic government. Extending these arguments to the individual level implies that these consequences have the potential to shape different experiences of democracy which form individual orientations towards government (Aarts and Thomassen 2008; Anderson and Guillory 1997; Rohrschneider 1999, 2005). The question that arises, though, is how precisely should these patterns of governance generated by different constitutional rules shape these experiences? There are contrasting logics implicit in the literature and we develop these into competing testable hypotheses in the discussion that follows.

The first argument we develop focuses on the possible accountability gap generated by constitutional rules granting prime ministers, cabinets and presidents discretion to call early elections. The ability to call early elections at a time that suits them creates the opportunity and incentive for prime ministers to dissolve parliament when they are likely to win and for presidents to time parliamentary elections when their allies may do well. Alastair Smith's (2004) important theoretical work highlights how incumbents have incentives to call early elections when they expect a downturn in policy performance and wish to bank current levels of support in the expectation of electoral support declining in the future. The empirical literature documents that that this is often a successful strategy. Incumbents receive an electoral bonus in votes, seats and the increased probability in prime ministerial survival in office as a result of carefully timing an election (Schleiter and Tavits 2016). The implication is that constitutional rules that permit the governments to call early elections will be used to increase incumbents' ability to secure advantageous electoral outcomes and as a result weaken the accountability link between politicians and citizens. This means, '[b]ecause leaders who can control election timing do 
not need to face the voters at fixed times ... such incumbents may be able to affect how voters vote by controlling when they vote ... and thereby affect (and sometimes distort) accountability' (Schleiter and Tavits 2016: 837). Smith (2004), for instance, finds, in the case of the UK, economic performance declines after early elections, something that incumbents who win elections have avoided taking responsibility for by calling early elections. Extending the implications of this argument to the democratic experience of citizens suggests that the more that constitutions permit early and opportunistic election calling, the more likely it is that the incumbent's evasion of electoral accountability will decrease satisfaction with democracy for those anticipating the opportunity to penalize them in the subsequent election. This leads to the first expectation that we test in this article:

Hypothesis 1: Citizens will express lower levels of satisfaction with democracy in countries with constitutional rules that permit prime ministers, presidents or cabinets to dissolve parliament compared with citizens of countries in which constitutional rules constrain the early dissolution of parliament.

In contrast, the second argument we develop emphasizes that granting the prime minister or the cabinet the power to call early elections enhances the quality of democratic government. These arguments can be traced as far back as Walter Bagehot (1867), who noted the power of the rule both to facilitate the passage of legislation and encourage the government to attend to public opinion (Bagehot 1867/2001: 16 and 163-179). In more recent work, Michael Laver (2008) has argued that endogenous election timing, controlled by the executive, facilitates democratic responsiveness to changing (i.e. more favourable) public opinion, which has an impact on policymaking. This is because the power to threaten to call early elections gives the executive significant bargaining advantages in negotiations with the legislature 'when the government is riding high in the polls and the parliamentary opposition fears an election, then the government's legislative business managers can adopt a "make my day" approach, staking the future of the administration on (quite possibly more extreme) legislative proposals' (Laver 2008: 124-125). Michael Becher and Flemming Juul Christiansen (2015) provide support to this argument, demonstrating that the conditions that shape the capacity of prime ministers to use the threat of early elections to extract policy concessions from parliament depends on their electoral popularity.

If granting early election calling powers to incumbents increases policy performance and government responsiveness, constraining early election calling may erode these attributes. Scholars of parliamentary government suggest that political manoeuvring in the assembly in the post-election period weakens the connection between governments and voters (Cheibub and Przeworski 1999; Mershon 2002; Maravall 2010). Restricting early election calling insulates politicians in parliament from the immediate threat of an election. In-between elections the legislature has discretion to select and remove cabinets and there is less need to be immediately responsive to the concerns of the electorate as they do so: 'Elites may co-ordinate with one another in ways that voters and theorists alike find troubling ... The spectacle of newly elected office holders switching parties can undermine voter confidence and the links that ensure democratic responsiveness' (Powell 2004: 98-99). 
José Antonio Chiebub and Adam Przeworski (1999) chart that nearly half of heads of government leave office without voters being asked to vote on their performance. They note that interparty disputes end almost two-thirds of all prime ministers' careers during the parliamentary term rather than at election time (Cheibub and Przeworski 1999: 236). José María Maravall argues it is precisely these kind of non-electoral government terminations that mean 'that coalitions can limit the democratic accountability of governments' (see also Hellwig and Samuels 2008: 70-71; Maravall 2010: 98). It is these replacement governments that will be more likely if dissolution is constrained (Schleiter and Morgan-Jones 2009).

The argument is that constrained dissolution increases the capacity of members of parliament to overturn cabinets because members of the legislature do not face the immediate threat of pre-term dissolution. As it is easier for governments to be removed in the inter-election term, the less likely it is that governments can be held accountable at election time for their actions taken earlier in the term. This in turn reduces the incentive that elections provide to govern in the interests of the electorate, increasing the chance that these rules will reduce the quality of democratic government. Thus, the effect of constitutional rules that constrain early election on increasing the rate of non-electoral replacements government may cause citizens to evaluate their experience of democracy negatively. In contrast, governments can be expected to be more responsive and policy effective when prime ministers and cabinets have discretion about when to dissolve the parliament, which should improve perceptions of democratic quality at the individual level compared with constrained dissolution. This leads us to our second hypothesis:

Hypothesis 2: Citizens will express lower levels of satisfaction with democracy under constitutional rules that constrain the early dissolution of parliament compared to citizens of countries that permit prime ministers, presidents or cabinets to dissolve parliament.

Thus, we have two competing arguments which are the direct inverse of each other about the effect of constitutional rules governing early election calling on citizen satisfaction with democracy.

A second set of literature enables us to develop insights that allow us to theorize about differences in the effect of calling early elections on citizen evaluations of incumbent performance, with implications for democratic quality at the time early elections are called. Whereas the previous discussion focused on expected differences between average levels of democratic satisfaction between countries with different constitutional rules, here we consider the short-run effects of early election calling compared to regular elections in countries with permissive early election calling rules (prime-ministerial initiated, presidentially controlled or agreed by the cabinet).

This literature starts from the observation that the act of calling early elections sends a signal to voters about incumbent quality (Smith 2004), and this signal is negative. Smith argues that governments call early elections in economic good times because they anticipate a future decline in economic performance. Importantly the earlier the election is called in this argument the stronger the signal of negative outcomes. This negative signal causes citizens to update their perception of government performance, leading to a decline in incumbent electoral support. A 
range of evidence supports this argument. Smith (2004) provides evidence at the aggregate level in the UK that when early elections are called, incumbents lose support over the course of the campaign, though they usually win. André Blais et al. (2004) and Jean-François Daoust and Gabrielle Péloquin-Skulski (2021) provide individual-level observational evidence from Canada that a portion of voters punish incumbents more when elections are called early. Schleiter and Tavits (2018) provide individual-level survey-experimental evidence that when incumbents call early elections that are perceived as an opportunistic unfair use of their powers, then voter support for incumbents declines. They find that although voters' concerns about electoral opportunism do have some electoral costs for the incumbents, consideration about 'economic performance strongly dominates any concern about opportunism in structuring vote choice' (Schleiter and Tavits 2018: 1193). This means we can expect opportunistic election calling to be a successful strategy for incumbents; yet it may be a strategy that makes, at least some, voters unhappy with the quality of democracy. Calling elections opportunistically then in this view can heighten voter perceptions of procedural unfairness, leading perceptions of democratic quality to decline.

This literature focuses entirely on the case of opportunistic early elections defined as elections procedurally triggered by incumbents to maximize chances of re-election, but early elections can also result from governance failure. Parliamentary dissolutions can be triggered either by opposition action (such as a no-confidence vote) or by the government calling an early election in response to governance failures such as loss of support for the government's legislative program, loss of parliamentary confidence, withdraw of a coalition partner, resignation of the PM, or the imminent occurrence of any of these events' (Schleiter and Tavits 2016: 842). Although voter responses to these types of early elections are comparatively understudied, it is reasonable to expect that voters will also become more democratically dissatisfied when elections are early, compared with regular elections. In addition, we can expect this dissatisfaction to be more prevalent when it is individual figures such as prime ministers or presidents who are responsible for these decisions as they will be seen to be acting in a more partisan way or associated more clearly with governance failure.

Finally, we can draw on Smith's arguments that the negative signal about incumbent expectations of future performance is stronger the earlier elections are called relative to expectations. 'If elections are announced out of the blue - when other factors predict an election to be unlikely - then the timing decision indicates that the leader anticipates a drastic decline in future performance. Voters can use this new information to reassess their evaluation of the government' (Smith 2004: 5). If we assume that such out-of-the-blue early elections, signalling poor incumbent quality, are more likely earlier in the parliamentary term, then we might expect these elections to be related to lower levels of democratic satisfaction. These considerations lead to our final hypotheses:

Hypothesis 3: Citizens will express lower levels of satisfaction with democracy when early elections are called compared with regular elections.

Hypothesis 4: Citizens will express lower levels of satisfaction with democracy when early elections are called by presidents and prime ministers compared with regular elections as well as early elections called by cabinets. 
Hypothesis 5: Citizens will express lower levels of satisfaction with democracy when early elections are called by presidents and prime ministers, especially for those called further away from regularly scheduled parliamentary elections.

This completes our theoretical discussion that identified our expectations for how constitutional rules governing early election calling may shape democratic satisfaction across polities in different ways and suggesting democratic satisfaction will decline specifically after early elections called by prime ministers and presidents, and those called earlier in the parliamentary term.

\section{Data, measurement and methods}

In order to test the theory as set out in this article, we use every wave of the ESS from 2002 to 2016 (Rounds 1-8). This allows us to control for the theorized determinants of satisfaction with democracy at the individual level. We merged these data with information on constitutional rules on early election calling, including when early elections were called. Using the Comparative Political Data Set (Armingeon et al. 2018), we identify the winners and losers of each election and include a control variable for the effective number of parties. We additionally include yearly data from the World Bank for GDP per capita growth, unemployment and inflation, as well as the Gini Index of income inequality (Solt 2019). We included an additive variable for government performance from the World Governance Indicators. Finally, we added an age of democracy (from 2016) and dummy variables for both semi-presidentialism and post-communism. A full description of all variables and measurements can be found in the Online Appendix.

For the dependent variable - satisfaction with democracy - we use the survey question, 'And on the whole, how satisfied are you with the way democracy works in [country]?' (Anderson 2005). For the sample used here: range 0-10; mean: 5.59; std dev.: $2.41 ; N=161,694$. Citizens' satisfaction with democracy is an important measure of national-level democracy. While some have argued that citizens' satisfaction with democracy problematically takes on several facets of the relationship between citizens and government (also Canache et al. 2001; Linde and Ekman 2003), Christopher Anderson (2005) emphasizes how citizens' orientations to and subsequent evaluations of their (own) democracy must correspond to what they consider to be 'democratic' (Easton 1975). This includes, in Estonian language, both diffuse (what an object is or represents) and specific (what a system produces) support. The former is the generic and positive orientation to the democratic process (e.g. 'I like democracy'), whereas specific support is an 'experiential', performance assessment (e.g. 'I like my democracy'). Both are meaningful and very often correlated and, as Anderson points out, 'the object of a citizen's support does not have to be - and probably cannot be - reliably separated in terms of the system and the system's outputs' (2005: 4). Thus, our use of 'citizens' own assessments of their democracy as a measuring rod' (Powell 2004: 102) is appropriate as an assessment of the performance of democracy.

Our main (independent) variable of interest requires us to code constitutions with respect to the degree that they permit or constrain early parliamentary 
dissolution and the main actors that have some say over this decision. To measure the constitutional rules governing early election calling we follow Petra Schleiter and Edward Morgan-Jones's (2009) typology, which classifies countries according to the extent that the constitutionally dominant actor in early election calling is either the prime minister, the cabinet or the president - or if early election calling is constrained. ${ }^{1}$ It is important to point out that parliamentary dissolutions are part of constitutions generally chosen when counties democratize and supermajority requirements make these rules extremely difficult to change (the UK is an exception). It is therefore reasonable to regard these rules as exogenously determined.

Table 1 provides an overview of the countries in our sample and the rules under which they are governed. In Tables 2 and 3 we also provide descriptive information about the relationship of these rules to patterns of government early election calling and cabinet termination. In the data that we use, early elections are counted purely in terms of the number of days before constitutionally mandated elections are expected to be held. These elections vary between 40 and 1,253 days before the month in which next election could expect to be scheduled according to the constitutional requirements that limit the parliament's term. A median early election falling 12.1 months before the next regular election could expect to be scheduled (mean: 14.2; std dev. =11.5). Opportunistic elections are coded as such when 'they are (i) triggered by the incumbent government and (ii) there is evidence of opportunism by the incumbent, defined as capitalizing on public opinion support, strong performance of the government, or opposition weakness (unpopularity, divisions, leaderlessness)' (Schleiter and Tavits 2016: 840).

Note that both early elections and opportunistic elections are anticipated much more frequently under constitutional rules, where prime ministers can time elections, and non-electoral replacements much less frequently (columns 4 and 5 in Table 2). ${ }^{2}$ The table also displays data demonstrating that when early election calling is constrained, the numbers of both early elections and opportunistic elections are much lower and also the rate of non-electoral replacement is much higher (compare results along columns 3 and 4, Table 3). These data serve to confirm that there is a potential link between the constitutional rules and patterns of early election calling.

The standard model for individuals' satisfaction with democracy is a multilevel model with both individual- and macro-level variables playing important roles in determining individual satisfaction levels. To address the wide range of control variables that the existing literature identifies as significant correlates of democratic satisfaction we include measures for the following concepts. For 'experiences with democratic institutions' (Rohrschneider 1999, 2005), we use an additive indicator of the number of 'democratic activities', including saying 'yes' to contacting a politician or government official in the previous 12 months; working in a political party or action group in the previous 12 months; working in another organization or association in the previous 12 months; wearing or displaying a campaign badge/ sticker in the previous 12 months; signing petitions in the previous 12 months; or taking part in a lawful public demonstration in the previous 12 months $(N=6 ; \alpha$ : 0.630 ). For 'outputs of democratic institutions' such as their capacity for managing both the national economy and its effects on personal economic conditions (also Anderson 1998; Finkel et al. 1989; Lewis-Beck 1986; Listhaug and Wiberg 1995; 
Table 1. Countries and Constitutional Rules

\begin{tabular}{|c|c|c|c|}
\hline $\begin{array}{l}\text { Prime ministerial } \\
\text { dissolution }\end{array}$ & $\begin{array}{l}\text { Cabinet/majority } \\
\text { dissolution }\end{array}$ & $\begin{array}{l}\text { Presidential unilateral } \\
\text { dissolution }\end{array}$ & $\begin{array}{l}\text { Constrained } \\
\text { dissolution }\end{array}$ \\
\hline Denmark & Austria & France & Bulgaria \\
\hline Finland (from 1991) & Belgium & Iceland & Czech Republic \\
\hline Ireland & Greece (from 1986) & Italy & Germany \\
\hline Spain & Hungary & Portugal & Estonia \\
\hline \multirow[t]{9}{*}{ United Kingdom } & Luxemburg & & Latvia \\
\hline & The Netherlands & & Lithuania \\
\hline & & & Moldova \\
\hline & & & Poland \\
\hline & & & Romania \\
\hline & & & Russia \\
\hline & & & Slovakia \\
\hline & & & Slovenia \\
\hline & & & Ukraine \\
\hline
\end{tabular}

Wagner et al. 2009) and for 'the problem-solving capabilities of democracy' (Sarsfield and Echegaray 2006: 169), we use the question, 'On the whole how satisfied are you with the present state of the economy in [country]?'3

For 'winners and losers' (Anderson and Guillory 1997; see also Blais and Gélineau 2007; Singh et al. 2012), we matched individuals' most recent vote with the current party composition in government (Comparative Political Data Set CPDS). Winners are those who voted for parties in the governing coalition, losers were those who voted, but not for winning parties. We also keep with the literature by including 'ideological' winners (also referred to as 'quasi-winners'). These are voters who did not vote for a winning party but have ideological proximity to the current government. Matching these provides some ideological congruence between voters and current government composition as well as policy positions (Kim 2009). Individuals' self-reported ideological positions were grouped into three categories (0-3: left; 4-6: centre; 7-10: right) and matched to CPDS: (1) 'Government position: "Hegemony of left parties" and "Dominance of left parties"; (2) 'Balance of power between left and right'; and (3) 'Dominance of right/centre parties' and 'Hegemony of right/centre parties'.

We include measures for consensual v. majoritarian systems; age of democracy; political institutions' capabilities; as well as dummies for both post-communism and semi-presidentialism. For the perception of 'representativeness' in consensual systems and 'accountability' in majoritarian systems (Aarts and Thomassen 2008; Anderson and Guillory 1997), according to the theory, the proportionality of the electoral system should affect the identifiability and representative of governments and therefore perceptions of representation and accountability that feed into satisfaction with democracy. As a measure of the variation between consensual v. 
Table 2. Constitutional Rules and Early Elections

\begin{tabular}{|c|c|c|c|c|c|}
\hline $\begin{array}{l}\text { Constitutional } \\
\text { rules }\end{array}$ & $\begin{array}{l}\text { Frequency of } \\
\text { regular election }\end{array}$ & $\begin{array}{l}\text { Frequency of } \\
\text { early election }\end{array}$ & $\begin{array}{c}\text { Frequency of } \\
\text { opportunistic elections }\end{array}$ & $\begin{array}{c}\text { Early elections as a } \\
\text { proportion of all } \\
\text { elections }\end{array}$ & $\begin{array}{l}\text { Opportunistic elections as a } \\
\text { proportion of all elections }\end{array}$ \\
\hline \multicolumn{6}{|c|}{ Prime minister power to initiate parliamentary dissolution } \\
\hline Denmark & 2 & 20 & 10 & 0.91 & 0.45 \\
\hline Ireland & 2 & 17 & 8 & 0.89 & 0.42 \\
\hline Spain & 3 & 6 & 3 & 0.67 & 0.33 \\
\hline UK & 3 & 12 & 10 & 0.80 & 0.67 \\
\hline $\begin{array}{l}\text { Finland since } \\
1991\end{array}$ & 5 & 0 & 0 & 0.00 & 0.00 \\
\hline Total & 15 & 55 & 31 & 0.79 & 0.44 \\
\hline \multicolumn{6}{|c|}{ Cabinet or parliamentary majority timing } \\
\hline Austria & 9 & 5 & 2 & 0.36 & 0.14 \\
\hline Belgium & 8 & 12 & 2 & 0.60 & 0.10 \\
\hline Hungary & 5 & 0 & 0 & 0.00 & 0.00 \\
\hline The Netherlands & 9 & 8 & 3 & 0.47 & 0.18 \\
\hline Sweden & 18 & 1 & 0 & 0.05 & 0.00 \\
\hline Total & 49 & 26 & 7 & 0.53 & 0.09 \\
\hline \multicolumn{6}{|l|}{ President timing } \\
\hline France & 9 & 5 & 0 & 0.36 & 0.00 \\
\hline Portugal & 5 & 8 & 0 & 0.62 & 0.00 \\
\hline Total & 14 & 13 & 0 & 0.48 & 0.00 \\
\hline
\end{tabular}


Table 2. (Continued.)

\begin{tabular}{|c|c|c|c|c|c|}
\hline $\begin{array}{l}\text { Constitutional } \\
\text { rules }\end{array}$ & $\begin{array}{l}\text { Frequency of } \\
\text { regular election }\end{array}$ & $\begin{array}{l}\text { Frequency of } \\
\text { early election }\end{array}$ & $\begin{array}{c}\text { Frequency of } \\
\text { opportunistic elections }\end{array}$ & $\begin{array}{l}\text { Early elections as a } \\
\text { proportion of all } \\
\text { elections }\end{array}$ & $\begin{array}{l}\text { Opportunistic elections as a } \\
\text { proportion of all elections }\end{array}$ \\
\hline \multicolumn{6}{|c|}{ Constrained dissolution } \\
\hline Bulgaria & 3 & 2 & 0 & 0.40 & 0.00 \\
\hline Estonia & 4 & 0 & 0 & 0.00 & 0.00 \\
\hline Germany & 13 & 3 & 2 & 0.19 & 0.13 \\
\hline Slovakia & 3 & 3 & 0 & 0.50 & 0.00 \\
\hline Slovenia & 5 & 1 & 0 & 0.17 & 0.00 \\
\hline Total & 29 & 11 & 2 & 0.28 & 0.05 \\
\hline
\end{tabular}

Sources: Schleiter and Morgan-Jones (2009), augmented using Andersson et al. (2012); the European Representative Democracy Data Archive (www.erdda.se); Keesings; and the EJPR Political Data Yearbook. 
Table 3. Constitutional Rules and Discretionary Government Terminations

\begin{tabular}{llcc}
\hline & & $\begin{array}{c}\text { Early elections } \\
\text { as a proportion } \\
\text { of all } \\
\text { discretionary }\end{array}$ & $\begin{array}{c}\text { Non-electoral } \\
\text { replacements as } \\
\text { a proportion of } \\
\text { all discretionary } \\
\text { Constitutional }\end{array}$ \\
$\begin{array}{l}\text { Frequency } \\
\text { of early } \\
\text { election }\end{array}$ & $\begin{array}{c}\text { Frequency of } \\
\text { non-electoral } \\
\text { replacements }\end{array}$ & $\begin{array}{c}\text { government } \\
\text { terminations }\end{array}$ & $\begin{array}{c}\text { government } \\
\text { terminations }\end{array}$ \\
\hline
\end{tabular}

Prime minister power to initiate parliamentary dissolution

$\begin{array}{lcccc}\text { Denmark } & 20 & 4 & 0.83 & 0.17 \\ \text { Ireland } & 17 & 4 & 0.81 & 0.19 \\ \text { Spain } & 6 & 1 & 0.86 & 0.14 \\ \text { UK } & 12 & 4 & 0.75 & 0.25 \\ \text { Finland since } & 0 & 4 & 0.00 & 1.00 \\ 1991 & & & & 0.24 \\ \text { Total } & 55 & 17 & 0.76 & \end{array}$

Cabinet or parliamentary majority timing

\begin{tabular}{lcccc}
\hline Austria & 5 & 5 & 0.50 & 0.50 \\
\hline Belgium & 12 & 16 & 0.43 & 0.57 \\
\hline Hungary & 0 & 3 & 0.00 & 1.00 \\
\hline $\begin{array}{l}\text { The } \\
\text { Netherlands }\end{array}$ & 8 & 5 & 0.62 & 0.38 \\
\hline Sweden & 1 & 4 & 0.20 & 0.80 \\
\hline Total & 26 & 33 & 0.44 & 0.56 \\
\hline President timing & & & & \\
\hline France & 5 & 10 & 0.33 & 0.67 \\
\hline Portugal & 8 & 3 & 0.73 & 0.27 \\
\hline Total & 13 & 13 & 0.50 & 0.50 \\
\hline Constrained dissolution & & & & 0.60 \\
\hline Bulgaria & 2 & 3 & 0.40 & 1.00 \\
\hline Estonia & 0 & 7 & 0.00 & 0.80 \\
\hline Germany & 3 & 12 & 0.20 & 0.82 \\
\hline Poland & 2 & 9 & 0.18 & 0.40 \\
\hline Slovakia & 3 & 2 & 0.60 & 0.83 \\
\hline Slovenia & 1 & 5 & 0.17 & 0.78 \\
\hline Total & 11 & 0.22 & $R$ \\
\hline
\end{tabular}

Sources: Schleiter and Morgan-Jones (2009), augmented using Andersson et al. (2012); the European Representative Democracy Data Archive (www.erdda.se); Keesings; and the EJPR Political Data Yearbook.

majoritarian systems, we include a measure of the effective number of parties (Laakso and Taagepera 1979).

To account for cross-national variation, we include determinants of variation in satisfaction with democracy at the macro-level model. The model is a random 
intercept/fixed slope model. Individual-level variation is fixed across countries (i.e. slopes are not allowed to vary across countries) but country means are allowed to vary cross-nationally by the included macro-level variables. We do not consider the case in which macro-level variation may shape cross-national variation of individual-level variables as there is no theoretical impetus at this stage to do so. The variables specifically theorized to impact satisfaction with democracy are included in Level 1.

\section{Results}

The central research question is whether provisions for early election calling affect citizens' satisfaction with democracy, and if so, which rules and how. Thus, we must answer two questions: one, does having constitutional rules for early elections change individuals' satisfaction with democracy, and if so, are any particular types implicated? And, two, is having such rules sufficient or do they need to be used to affect satisfaction levels?

In Table 4, we can see the results of our analysis (regression coefficients and $\mathrm{t}$-scores). Model 1 includes the key variables of interest, namely, the constitutional rules for early election calling by type and the actual calling of election by type. Model 2 presents a model without these variables and the standard model of satisfaction with democracy, including both individual- and macro-level determinants from the literature. Model 3 reintroduces the constitutional rules for early election calling by type to the fully specified standard model. This allows us to test both Hypotheses 1 and 2 derived from unresolved questions in the literature about the role of early election rule and legitimacy.

We find evidence that citizens in countries in which there are constitutional rules for early election calling by cabinets appear to have lower levels of satisfaction than citizens of countries that constrain such dissolution (confidence level 95\%). Neither countries with constitutional rules for prime ministers nor those with rules for presidents have different levels from countries that constrain such dissolution. Neither finding provides definitive support for either hypothesis.

In Model 4, we introduce whether an early election was called at any time. The presence of constitutional provision for early election does not continue to shape satisfaction levels. However, elections that are called early, undifferentiated by constitutional rules, do appear to lower satisfaction levels. This is strong support for Hypothesis 3.

Further delineating across type (Model 5), we find lower satisfaction levels are driven primarily by prime ministers' and presidents' actual early election calling. As theorized above, this may have to do with the 'one above all' appearance of a single person - in the form of a prime minister or president - calling early elections. This offers strong support for Hypothesis 4.

To understand the substantive impact of these variables, we can exploit the fact that the marginal effects of dummy variables are the same as the regression coefficients for dummy variables. Thus, we can see the amount by which satisfaction levels drop on the satisfaction with democracy scale (0-10): the levels drop -0.385 for prime ministers calling elections and -0.298 for presidents calling elections. These results are significant at $99.9 \%$ and $95 \%$ confidence, respectively. 
Table 4. Satisfaction with Democracy and Constitutional Rules for Early Elections

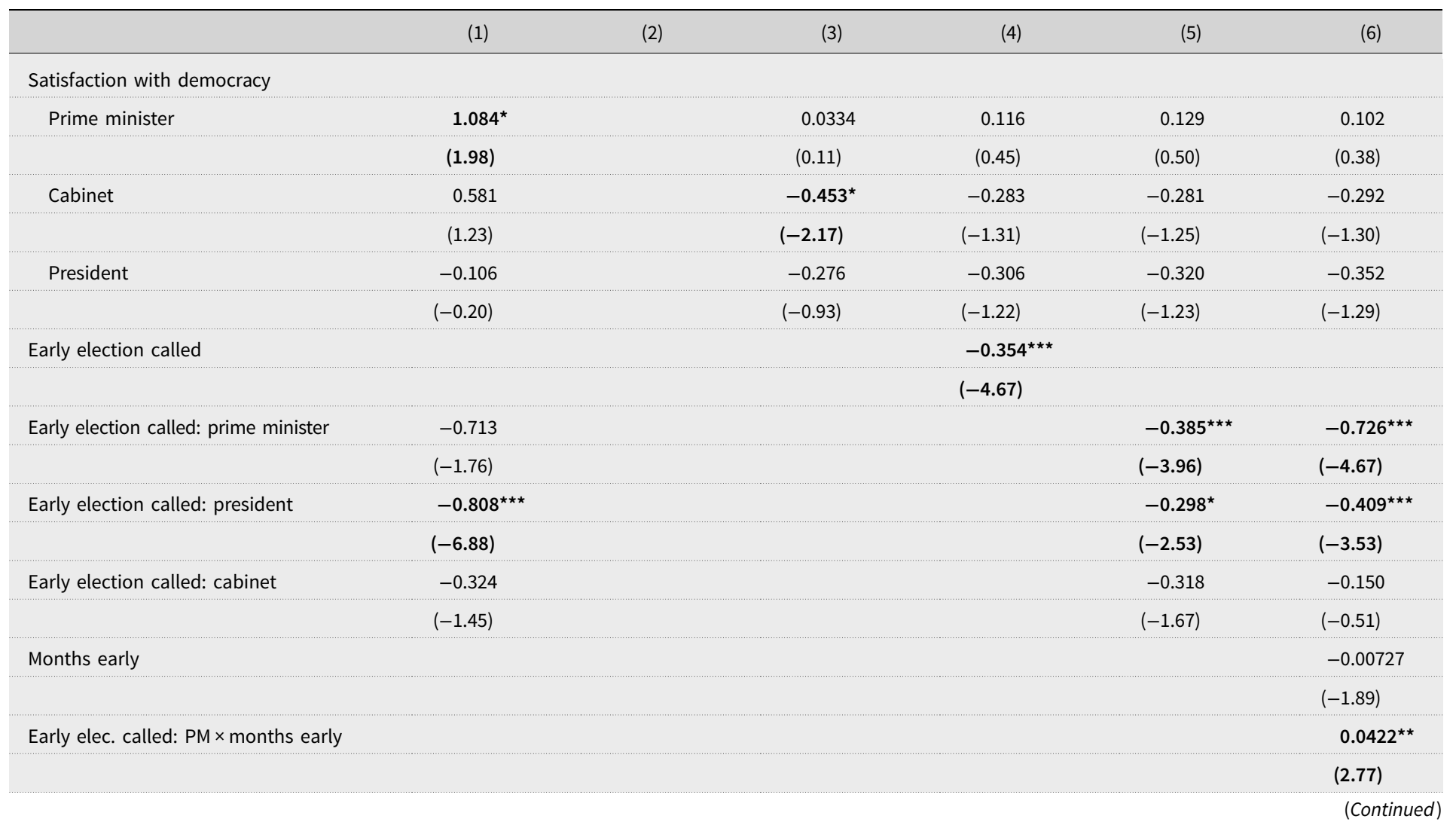


Table 4. (Continued.)

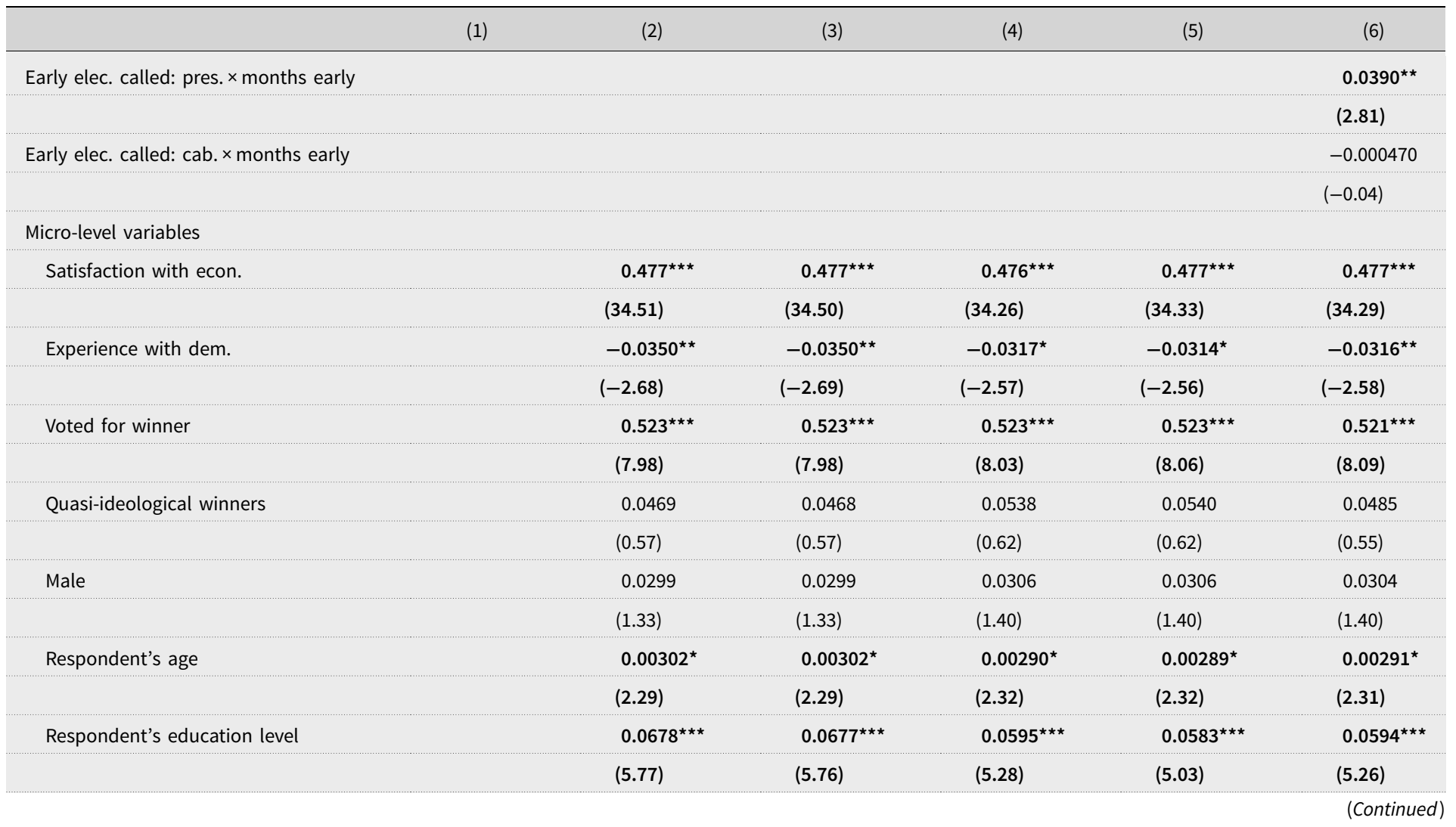


Table 4. (Continued.)

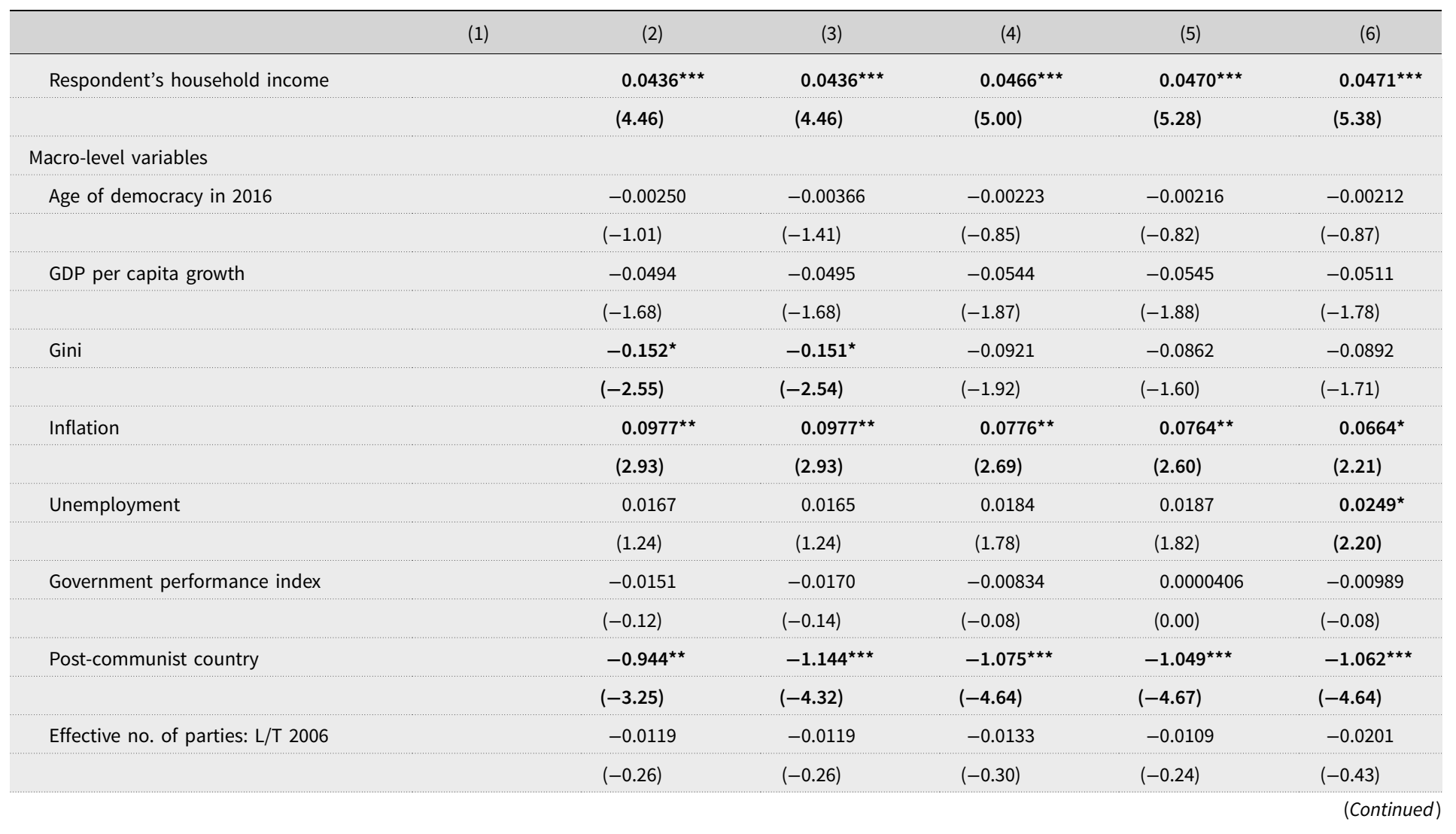


Table 4. (Continued.)

\begin{tabular}{|c|c|c|c|c|c|c|}
\hline & (1) & (2) & (3) & (4) & (5) & (6) \\
\hline Semi-presidential & & $(-0.99)$ & $(-1.26)$ & $(-1.19)$ & $(-1.22)$ & $(-1.54)$ \\
\hline Year of survey & & $(0.02)$ & $(0.02)$ & $(-1.13)$ & $(-1.14)$ & $(-0.77)$ \\
\hline Constant & $5.096^{\star \star \star}$ & 6.680 & 7.124 & 22.35 & 23.57 & 18.66 \\
\hline \multirow[t]{2}{*}{$\operatorname{Var}(S W D)$} & -0.0286 & $-0.733^{\star \star \star}$ & $-0.820^{\star \star \star}$ & $-1.046^{\star \star \star}$ & $-1.070^{\star \star \star}$ & $-1.073^{\star \star \star}$ \\
\hline & $(-0.22)$ & $(-4.89)$ & $(-4.78)$ & $(-6.86)$ & $(-7.14)$ & $(-6.89)$ \\
\hline \multirow[t]{2}{*}{$\operatorname{Var}($ Intercept) } & $0.831^{\star \star \star}$ & $0.696^{\star \star \star}$ & $0.696^{\star \star \star}$ & $0.695^{\star \star \star}$ & $0.695^{\star \star \star}$ & $0.694^{\star \star \star}$ \\
\hline & $(47.30)$ & $(46.31)$ & $(46.32)$ & $(45.96)$ & (45.93) & $(45.91)$ \\
\hline Observations & 161694 & 161694 & 161694 & 161694 & 161694 & 161694 \\
\hline
\end{tabular}




\section{Early Election timing before Scheduled Election}
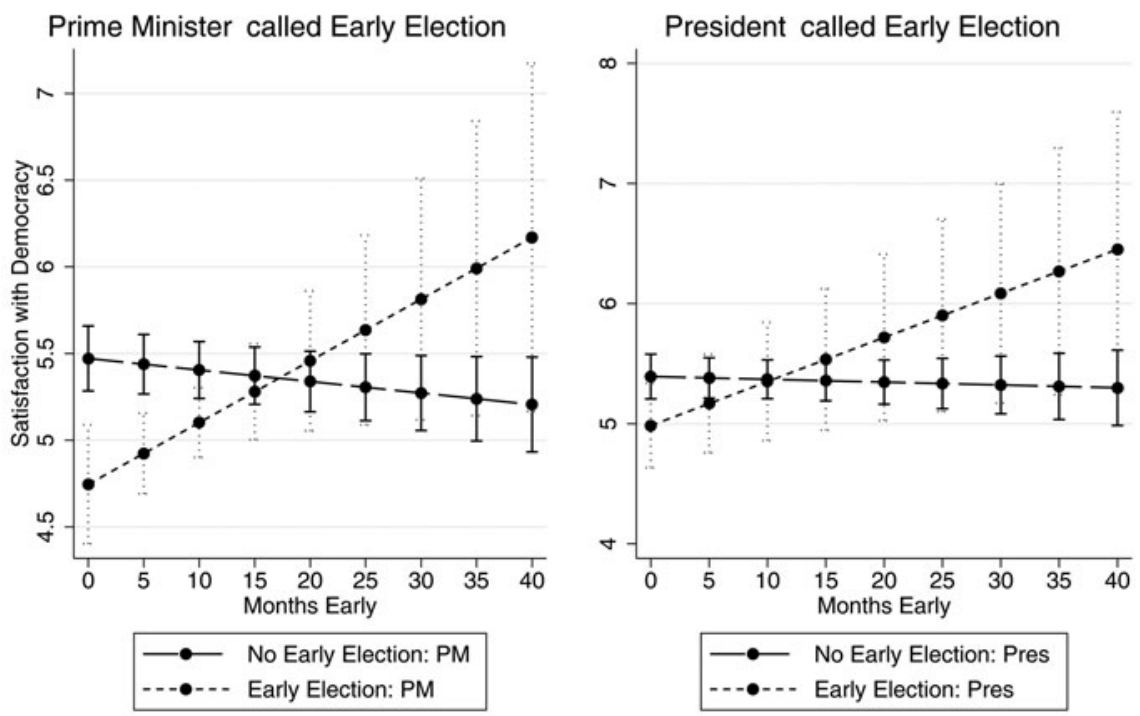

ESS 20022016

Figure 1. Early Election Timing before Scheduled Election Source: ESS 2011-16.

Finally, to test Hypothesis 5, Model 6 includes an interaction on the number of months early that each type of constitutional rule country called early elections. The interaction makes clear that while there continues to be a negative and statistically significant effect of prime minister and presidential early election calling, the time between when this early election is called and the scheduled parliamentary election shapes the intensity of this. Figure 1 shows a graphical representation of the interaction between early elections called by prime ministers and presidents and the time between the early and scheduled elections. In contrast to the expectation of Hypothesis 5, we find that the closer the early election is called in relation to the scheduled one, the lower satisfaction with democracy becomes. This is particularly evident when prime ministers called elections less than one year before the regularly scheduled elections.

Satisfaction with the performance of the economy, having voted for the winning party, greater age, education and income, all positively corelated with individuals' satisfaction levels (De Vries and Giger 2014). The negative democratic experience effect is a surprising but not unprecedented finding (Singh et al. 2012). Additionally, we can see that both greater inflation and unemployment are correlated with increasing satisfaction. This is not an uncommon finding (Ansolabehere et al. 2014; Singh et al. 2012) but one that lacks an explanation. We also find, consistent with the literature, that post-communist countries tend to have lower aggregate satisfaction levels.

The results of the model are robust to different model specifications. We estimated the model using a country $\times$ year dummy sometimes found in this, and 
similar, literatures. However, given the large number of theoretically demonstrated macro-level variables, the final model was hard to compare, bearing in mind the issue of collinearity and cases dropped by the estimating software. Likewise, substituting the set of important macro-level variables with a series of dummy variables is not theoretically tenable. We re-estimated the final model with an interaction on the winner/loser variable with no substantive change to the final model. ${ }^{4}$ We re-estimated the final model dropping each country to check for over-reliance on the performance of a single country, and there are no obvious issues. We re-estimated the final model replacing the effective number of parties with type of electoral system. We additionally found no meaningful difference by using dummies for both single-member, simple plurality systems and modified proportional representation, with proportional representation systems as the reference category. Finally, tests of multi-collinearity indicate insubstantial variance inflation. We also treated satisfaction with democracy, the dependent variable, with the range $0-10$, as an ordinal dependent variable. The results are unchanged and available from the authors.

\section{Conclusions}

There are two central findings. First, constitutional rules that permit or constrain governments from early election calling do not correlate significantly with democratic satisfaction. Some voices in this debate have pointed to the potential for opportunism and the evasion of accountability that may result from permitting early and opportunistic election calling; others have worried about the governance failures and the potential for parliamentary games rather than the electorate to shape government composition that constraining early election calling can bring. Yet, in terms of potential effects of early election calling on subjective perceptions of the quality of governance, the evidence provided here does not provide a case for the advantages of one or other configuration of constitutional rules on early election calling.

This article's second key finding is that when incumbent prime ministers and presidents call early elections, we find a subsequent and statistically significant decrease in democratic satisfaction in the period after the election is called. This finding is consistent with the literature that suggests early election calling does send a negative signal about incumbent quality even though incumbents may benefit electorally from calling early elections. This lowered satisfaction is more pronounced the closer to regularly scheduled parliamentary elections the early elections are called. This finding ran counter to the expectation that the earlier in the term elections are called the worse democratic satisfaction might be. We speculate here that early elections held relatively late in the term may heighten dissatisfaction, as it appears to be not just a strategic or opportunistic manoeuvre, but a successful one. Smith (2004), using UK data, finds that incumbents are more likely to lose, the earlier in the term they call elections, whereas they are more likely to win early elections called later in the term. Schleiter and Tavits (2018) suggest that voters are still likely to vote for governments even if they are perceived as opportunistic. If it is the case that prime ministers or presidents calling early elections late in the term are perceived as opportunistic, but win elections nevertheless, 
this might, we speculate, explain our finding of higher levels of democratic satisfaction for early elections later in the term. Voters can observe incumbents violating procedural fairness but nevertheless winning. Teasing this issue out is something that we leave to future research.

While this analysis provides both initial empirical evidence and an open agenda to explore whether calling early elections has any effect at all on voters' perceptions of democratic quality, there are several additional and promising areas for future research. As mentioned above, further attention could be given to unilateral presidential control of parliamentary dissolution for citizen satisfaction, for which there are few but potentially informative empirical cases. Another potential avenue for future research could draw on the larger empirical literature on the gap in satisfaction in democracy between 'winners' and 'losers'. Early elections, by abruptly rearranging who are the 'winners' and 'losers', may offer sufficiently radical change of contexts to probe the impact of how changes in electoral fortune affect the differential 'winning'/losing' effect on voters' satisfaction levels (although see Loveless 2021; Nemčok and Wass 2020). Third, more attention can be given to testing potential causal mechanisms in addition to the identification of the presence of such relationships. Our initial theorizing on the calling of early elections by prime ministers and presidents suggest something akin to an anti-democratic 'one above all' dimension. That is, in contrast to cabinets, early elections called by prime ministers and presidents could be perceived as either one person at the very border of democratic practice, straining democratic norms, or as one person acting in a too overtly self-interested partisan manner. Such perceptions or change in perceptions by voters require deeper investigation. Finally, at the broadest level, given the relatively limited set of cases to investigate this process, finding means to extend the range of countries and time periods examined and to more deeply interrogate the hypothesized mechanisms behind these patterns would advance this budding literature.

In any case, this is a debate that has had - and continues to have - real-world consequences for ongoing academic and policy debate about the consequences of constraining or permitting incumbents to call early elections. While the first democratic parliamentary constitutions transferred the power to dissolve the parliament from the monarch to the prime minister or cabinet, over time nearly all constitutional designers have sought to limit executive discretion (Schleiter and Morgan-Jones 2009: 497). The constitutions of newer parliamentary and semipresidential republics either restrict when early election can be called to particular contingencies (such as repeated failures to invest a new government after a vote of no confidence), which require multiple veto players to consent before early elections can be called, or exclusively grant the power to call early elections to a directly or indirectly elected president. A desire to limit potential prime ministerial opportunism when calling early elections motivates calls to restrict the prime minister's discretion to call early elections in Australia, New Zealand and Canada (Roy and Alcantara 2012). In the UK, such calls led to constitutional change: the Fixed Term Parliament Act 2011 now limits the prime minister's ability to call early elections in the UK to periods of government formation failure or to occasions when two-thirds of MPs can agree to the dissolution of parliament. However, at the time of writing in 2021, the government is proposing to overturn this legislation and once again give the prime minister in effect sole discretion to call early elections. 
Taken together, all these findings complement and extend our existing understanding of the effects of the constitutional regulation of early election calling on democratic processes, by identifying their effects not just on key political processes such as elections, cabinet termination and policymaking, but also on citizens' attitudes. The evidence provided here suggests that the use of these rules can shape democratic satisfaction in the short term and can be at least as important as some of the institutional and economic factors that the literature has already identified.

Supplementary material. The supplementary material for this article can be found at https://doi.org/10. 1017/gov.2021.44.

\section{Notes}

1 An alternative coding scheme would be to use the Goplerud and Schleiter (2016) index of parliamentary power, which provides a finer-grained measure of each individual actor's constitutional influence over the dissolution of parliament than our theory specifies and does not provide a measure of constrained dissolution.

2 These data cover patterns of government early elections and cabinet termination from 1945 or the first democratic election held in a country.

3 We found no satisfactory measure in the ESS for individuals' normative or ideological attachments to democracy as a system of governance (Anderson and Tverdova 2003; Seligson 2002). Several proxies were tried and ultimately excluded as the final results were substantively indifferent to their inclusion. We also originally included 'trust in democratic institutions' (Zmerli and Newton 2008) using an additive trust variable from questions about two key political institutions, namely, parliament and parties: 'How much do you trust: ... [country]'s parliament? [and] ... political parties?' $(N=2, \alpha=0.810)$. However, these variables are missing from ESS Round 1 . Their inclusion had no effect on the substantive output and are excluded so that we can include all eight rounds of the ESS.

4 There was a small positive effect that is only just statistically significant on presidential constitutional rules for early election calling (not the actual calling by the president). In an analysis with more than 160,000 observations, we are reluctant to include the test of this interaction for this marginal significance (versus the vastly more substantial statistical significance of the other findings). Given that we have seen here that such rules are unlikely candidates to explain this difference in satisfaction levels, the small statistical and substantive significance the limited space to drill down on this finding, we leave this for future research to engage and address.

\section{References}

Aarts K and Thomassen J (2008) Satisfaction with Democracy: Do Institutions Matter? Electoral Studies 27 (1), 5-18. https://doi.org/10.1016/j.electstud.2007.11.005.

Anderson CJ (1998) Parties, Party Systems, and Satisfaction with Democratic Performance in the New Europe. Political Studies 46(3), 572-588. https://doi.org/10.1111/1467-9248.00155.

Anderson CJ (2005) Good Questions, Dubious Inferences, and Bad Solutions: Some Further Thoughts on Satisfaction with Democracy. Center on Democratic Performance Working Paper, 116. Binghamton University, Department of Political Science, http://cdp.binghamton.edu.

Anderson CJ and Guillory CA (1997) Political Institutions and Satisfaction with Democracy: A Cross-National Analysis of Consensus and Majoritarian Systems. American Political Science Review 91(1), 66-81. https://doi.org/10.2307/2952259.

Anderson CJ and Tverdova YV (2003) Corruption, Political Allegiances, and Attitudes toward Government in Contemporary Democracies. American Journal of Political Science 47(1), 91-109. https://doi.org/10.1111/1540-5907.00007. 
Andersson S, Bergman T and Ersson S (2012) The European Representative Democracy Data Archive. www.erdda.se.

Ansolabehere S, Meredith M and Snowberg E (2014) Mecro-Economic Voting: Local Information and Micro-Perceptions of the Macro-Economy. Economics \& Politics 26(3), 380-410. http://dx.doi.org/10. 1111/ecpo.2014.26.issue-3.

Armingeon K, Wenger V, Wiedemeier F, Isler C, Knöpfel L, Weisstanner D and Engler S (2018) Comparative Political Data Set 1960-2016. Bern: Institute of Political Science, University of Berne.

Bagehot W (1867) The English Constitution. London: Thomas Nelson \& Sons.

Becher M and Christiansen FJ (2015) Dissolution Threats and Legislative Bargaining. American Journal of Political Science 59(3), 641-655. https://doi.org/10.1111/ajps.12146.

Blais A and Gélineau F (2007) Winning, Losing and Satisfaction with Democracy. Political Studies 55(2), 425-441. https://doi.org/10.1111/j.1467-9248.2007.00659.x.

Blais A, Gidengil E, Nevitte N and Nadeau R (2004) Do (Some) Canadian Voters Punish a Prime Minister for Calling a Snap Election? Political Studies 52(2), 307-323. https://doi.org/10.1111\%2Fj. 1467-9248.2004.00481.x.

Canache D, Mondak JJ and Seligson MA (2001) Meaning and Measurement in Cross-National Research on Satisfaction with Democracy. Public Opinion Quarterly 65(4), 506-528. http://dx.doi.org/10.1086/ 323576.

Cheibub JA and Przeworski A (1999) Democracy, Elections, and Accountability for Economic Outcomes. In Przeworski A, Stokes S and Manin B (eds), Democracy, Accountability, and Representation. New York: Cambridge University Press, pp. 222-250.

Chowdhury AR (1993) Political Surfing over Economic Waves: Parliamentary Election Timing in India. American Journal of Political Science 37(4), 1100-1118. https://doi.org/10.2307/2111545.

Claassen C (2020) Does Public Support Help Democracy Survive? American Journal of Political Science 64 (1), 118-134. https://doi.org/10.1111/ajps.12452.

Daoust JF and Péloquin-Skulski G (2021) What Are the Consequences of Snap Elections on Citizens' Voting Behavior? Representation 57(1), 95-108. https://doi.org/10.1080/00344893.2020.1804440.

De Vries CE and Giger N (2014) Holding Governments Accountable? Individual Heterogeneity in Performance Voting. European Journal of Political Research 53(2), 345-362. https://doi.org/10.1111/ $1475-6765.12033$.

Easton D (1975) A Re-assessment of the Concept of Political Support. British Journal of Political Science 5 (October), 435-437.

Evans G and Whitefield S (1995) The Politics and Economics of Democratic Commitment: Support for Democracy in Transition Societies. British Journal of Political Science 25, 485-514. https://doi.org/10. 1017/S0007123400007328.

Fearon JD (1999) Electoral Accountability and the Control of Politicians: Selecting Good Types versus Sanctioning Poor Performance. Democracy, Accountability, and Representation. In Przeworski A, Stokes S and Manin B (eds), Democracy, Accountability, and Representation. New York: Cambridge University Press, pp. 55-97.

Finkel SE, Muller EN and Seligson MA (1989) Economic Crisis, Incumbent Performance and Regime Support: A Comparison of Longitudinal Data from West Germany and Costa Rica. British Journal of Political Science 19(3), 329-351. https://doi.org/10.1017/S0007123400005512.

Goplerud M and Schleiter P (2016) An Index of Assembly Dissolution Powers. Comparative Political Studies 49(4), 427-456. https://doi.org/10.1177\%2F0010414015612393.

Hellwig T and Samuels D (2008) Electoral Accountability and the Variety of Democratic Regimes. British Journal of Political Science 38(01), 65-90. https://doi.org/10.1017/S0007123408000045.

Ito T (1990) The Timing of Elections and Political Business Cycles in Japan. Journal of Asian Economics 1 (1), 135-156. https://doi.org/10.1016/1049-0078(90)90011-O.

Ito T and Park JH (1988) Political Business Cycles in the Parliamentary System. Economics Letters 27(3), 233-238. https://doi.org/10.1016/0165-1765(88)90176-0.

Kayser MA (2005) Who Surfs, Who Manipulates? The Determinants of Opportunistic Election Timing and Electorally Motivated Economic Intervention. American Political Science Review 99(01), 17-27. https://doi.org/10.1017/S0003055405051464.

Kayser MA (2006) Trade and the Timing of Elections. British Journal of Political Science 36(03), 437-457. https://doi.org/10.1017/S0007123406000238. 
Kim M (2009) Cross-National Analyses of Satisfaction with Democracy and Ideological Congruence. Journal of Elections, Public Opinion and Parties 19(1): 49-72. https://doi.org/10.1080/ 17457280802568402 .

Laakso M and Taagepera R (1979) 'Effective' Number of Parties: A Measure with Application to Western Europe. Comparative Political Studies 12(1), 3-27. https://doi.org/10.1177/001041407901200101.

Laver M (2008) Legislatures and Parliaments in Comparative Context. In Weingast B and Wittman D (eds), The Oxford Handbook of Political Economy. Oxford: Oxford University Press, pp. 121-138.

Lewis-Beck M (1986) Comparative Economic Voting: Britain, France, Germany, Italy. American Journal of Political Science 30(2), 315-346. https://doi.org/10.2307/2111099.

Linde J and Ekman J (2003) Satisfaction with Democracy: A Note on a Frequently Used Indicator in Comparative Politics. European Journal of Political Research 42(3), 391-408. http://dx.doi.org/10. 1111/ejpr.2003.42.issue-3.

Listhaug O and Wiberg M (1995) Confidence in Political and Private Institutions. In Klingemann H-D and Fuchs D (eds), Citizens and the State. Oxford: Oxford University Press, pp. 298-322.

Loveless M (2021) When You Win, Nothing Hurts: The Durability of Electoral Salience on Individuals' Satisfaction with Democracy. Political Studies 69(3), 538-558. https://doi.org/10.1177/0032321720910356.

Loveless M and Rohrschneider R (2011) Public Perceptions of the EU as a System of Governance. Living Reviews in European Governance 3(1). www.livingreviews.org/lreg-2011-1.

Maravall JM (2010) Accountability in Coalition Governments. Annual Review of Political Science 13, 81100. https://doi.org/10.1146/annurev.polisci.071108.101919.

Mershon C (2002) The Costs of Coalition. Stanford: Stanford University Press.

Nemčok M and Wass H (2020) As Time Goes By, the Same Sentiments Apply? Stability of Voter Satisfaction with Democracy during the Electoral Cycle in 31 Countries. Party Politics, published early online, March. https://doi.org/10.1177/1354068820912466.

Palmer HD and Whitten GD (2000) Government Competence, Economic Performance and Endogenous Election Dates. Electoral Studies 19(2), 413-426. https://doi.org/10.1016/S0261-3794(99)00059-1.

Powell GB (2004) The Chain of Responsiveness. Journal of Democracy 15(4), 91-105. https://doi.org/10. 1353/jod.2004.0070.

Rohrschneider R (1999) Learning Democracy: Democratic and Economic Values in Unified Germany. Oxford: Oxford University Press.

Rohrschneider R (2005) Institutional Quality and Perceptions of Representation in Advanced Industrial Democracies. Comparative Political Studies 38(7), 850-874. https://doi.org/10.1177/0010414005276305.

Rose R and Mishler WTE (1994) Mass Reaction to Regime Change in Eastern Europe: Polarization or Leaders and Laggards? British Journal of Political Science 24, 159-182. https://doi.org/10.1017/ S0007123400009777.

Roy J and Alcantara C (2012) The Election Timing Advantage: Empirical Fact or Fiction? Electoral studies 31(4), 774-781. https://doi.org/10.1016/j.electstud.2012.06.005.

Sarsfield R and Echegaray F (2006) Opening the Black Box: How Satisfaction with Democracy and its Perceived Efficacy Affect Regime Preference in Latin America. International Journal of Public Opinion Research 18(2), 153-173. https://doi.org/10.1093/ijpor/edh088.

Schleiter P and Morgan-Jones E (2009) Constitutional Power and Competing Risks: Monarchs, Presidents, Prime Ministers, and the Termination of East and West European Cabinets. American Political Science Review 103(03), 496-512. https://doi.org/10.1017/S0003055409990062.

Schleiter P and Morgan-Jones E (2018) Presidents, Assembly Dissolution, and the Electoral Performance of Prime Ministers. Comparative Political Studies 51(6), 730-758. https://doi.org/10.1177/ 0010414017710267.

Schleiter P and Tavits M (2016) The Electoral Benefits of Opportunistic Election Timing. Journal of Politics 78(3), 836-850. https://doi.org/10.1086/685447.

Schleiter P and Tavits M (2018) Voter Reactions to Incumbent Opportunism. Journal of Politics 80(4), 1183-1196. https://doi.org/10.1086/698758.

Seligson MA (2002) The Impact of Corruption on Regime Legitimacy: A Comparative Study of Four Latin American Countries. Journal of Politics 64(2), 408-433. https:/doi.org/10.1111/1468-2508.00132.

Singh S, Karakoc E and Blais A (2012) Differentiating Winners: How Elections Affect Satisfaction with Democracy. Electoral Studies 31(1), 201-211. https://doi.org/10.1016/j.electstud.2011.11.001.

Smith A (2004) Election Timing. Cambridge: Cambridge University Press. 
Solt F (2019) Measuring Income Inequality across Countries and over Time: The Standardized World Income Inequality Database. SWIID Version 8.1, May 2019, https://fsolt.org/swiid/.

Strøm K and Swindle SM (2002) Strategic Parliamentary Dissolution. American Political Science Review 96(3), 575-591. https://doi.org/10.1017/S0003055402000345.

Wagner AF, Schneider F and Halla M (2009) The Quality of Institutions and Satisfaction with Democracy in Western Europe - A Panel Analysis. European Journal of Political Economy 25(1), 30-41. https:/doi. org/10.1016/j.ejpoleco.2008.08.001.

Zmerli S and Newton K (2008) Social Trust and Attitudes toward Democracy. Public Opinion Quarterly 72(4), 706-724. https://doi.org/10.1093/poq/nfn054.

Cite this article: Morgan-Jones E, Loveless M (2021). Early Election Calling and Satisfaction with Democracy. Government and Opposition: An International Journal of Comparative Politics 1-25. https:// doi.org/10.1017/gov.2021.44 